\section{Hints to Travellers}

Eleventh edition. Vol. 2 : Organization and Equipment, Scientific Observation, Health, Sickness and Injury. Edited by the Secretary with the help of many Travellers. Pp. xv +472. (London: Royal Geographical Society, 1938.) 14s.

7 HE new edition of this second volume of "Hints to Travellers" is to all intents a new book. Former editions treated of little besides medical and surgical care and hints on the scope and methods of scientific inquiry. These matters are not neglected and the sections dealing with them have been recast In addition, however, there are thirteen chapters on organization, clothing, equipment, food transport, etc., in fact on every aspect of the fitting out and management of an exploring party. This is perhaps the most valuable part of the book, for it embodies the experience of many different travellers of recent years.

Polar travel looms large, but then, as the editor says, it marks a present trend in exploration, and so must command attention. Moreover, it is in polar travel that the technique has changed most in recent years. There are many extracts from the writings of recent travellers which may appear to occupy much space in a book the bulk of which must be kept within small dimensions for the sake of the traveller. On the other hand, these extracts have been carefully chosen, and each stresses some matter of importance even if it is a detail easily overlooked. Food and food values receive much attention, and photography has a long section : even the narrative volume of the expedition, written on its return, is not ignored.

The volume is valuable in every chapter, an indispensable handbook for any traveller off the beaten track and an expression of the care and critical judgment of its editor.

Railways To-day

By J. W. Williamson. (The Pageant of Progress Series.) Pp. $160+23$ plates. (London, New York and Toronto: Oxford University Press, 1938.) 3s. 6d. net. NR. J. W. WILLIAMSON will be known to 1 many men of science as the former secretary of the British Scientific Instrument Research Association. He has a facile pen and also hobbies, one of which is the study of railways and their working. The opening chapter in the book under notice touches on conditions of transport in Great Britain during the sixteenth century, the development of roads in later years and eventually of the 'rail way', from which the modern railway arose early in the nineteenth century. Succeeding chapters discuss individual aspects of railway transport, such as the track, the locomotive, building and repairing rolling stock, signalling, operating traffic, traffic control, and so on, with a concluding chapter on electric traction. The book is well illustrated with plates and explanatory diagrams. To the mechanically minded boy, and also to those of his elders who still regard the railway as something more than a necessary means of transport, it will be of absorbing interest.
The Nature of Man:

Studies in Optimistic Philosophy. By Prof. Élie Metchnikoff. The English translation edited by Sir P. Chalmers Mitchell. Revised and brought up to date by C. M. Beadnell. Pp. xviii +210. (London : Watts and Co., 1938.) 58. net.

WE welcome the new edition of this lively and attractive work, of which the first translation appeared thirty-five years ago (see NATURE, 70, 394 ; 1904). The book has been ably revised by RearAdmiral C. M. Beadnell, who in addition to several footnotes has added appendixes dealing with artificial insemination, blood transfusion, ages at marriage, illegitimate births in different countries, suicide, infant mortality and other matters. The work begins with a historical sketch showing that while natural philosophers in all ages have sought the foundation of morality in human nature itself and have held human nature to be good, many religious doctrines, especially Buddhism and Christianity, have depreciated the body as compared with the soul.

In the following chapters the harmonies and disharmonies first among beings inferior to man and then in the human race are discussed, special attention being paid to the disharmonies in the organization of the digestive and reproductive systems, as exemplified by the presence of rudimentary organs and disharmonies before and after marriage. The part played by science in combating disease is then considered, and the final chapters are devoted to the scientific study of old age and death, which the author maintains will probably bring about great modifications in the course of the last period of life.

\section{Human Powers and Their Relations}

By K. W. Monsarrat. Pp. xvi+289. (Liverpool : University Press of Liverpool ; London: Hodder and Stoughton, Ltd., 1938.) 10s. 6d. net.

7 HIS book offers an excellent example of construetive thinking in theoretical and practical philosophy. The problem of knowledge forms its central theme, and is taken as the basis of a more rational organization of human relations. Knowing is conceived as a process which produces and presents reports or ideas. The proper use of ideas leads to the conception of the world in terms of power, and not in terms of matter. The classical dualism between power and matter should not be referred to the world as such, but to a duality in the relations of the process of knowing.

Applied to social problems, these views involve the consideration of the world as composed of diverse power-items which compensate each other without fusion in assemblies or associations : the human being is thus conceived as an example of influence-assembly, which retains his freedom and individuality. Society is the combination of human beings according to the same metaphysical process. The interest of these views, as we understand them, is to be found in the conception of an idealist philosophy which preserves the relative independence of the individual. In contrast with the misguided application of idealism by totalitarian States, the vision implied in this book will be found both useful and refreshing. ' $\mathrm{C}$. G. 